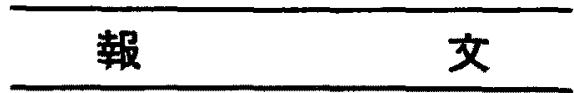

（昭和 24 年 9 月 11 日受理）

\title{
新しい纎維斷面作製法と二, 三の合成繊維への㗹用
}

東京工業大學 牧島邦夫

\section{要旨}

硝较戴維素(セルロイドの原料として用いられるN 量 $10 \%$ 程度のもの)をメタノールとニーテルとの混 合液にとかして，この溶液を包埋用に用いて極めて良 結果を得た。との夜で包理すると，その乾燥狀態に於 ける固さが丁度瀻維の固さと同程度になり，しかも雨 者のなじみは極めてよく，2〜3 $\mu$ 位の厚さの切片を作 つても瀻維は眖離することがないこの包埋物は70一 80\%のメタンールの中で長く保存するこ上ができる。 との方洗を用いて，ビ二ロン，サイン，ビスコース ステーブル等の切品面を作つた。

\section{舶言}

瀻維の横断面を检鏡する祭にはこれを出來るだけ溥 く切らなければならない。このためには色々な方法が

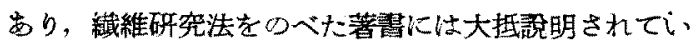
る。その中で简便泩としてにわとこの心で瀻維を保持 して切断面をとる方洗があるが，これは主として植物

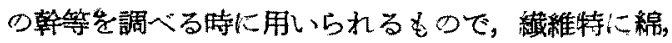
絹等では薄い切片を作ることができない。

次に最も廣く用いられるパフフイン法が焉るが、こ

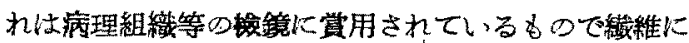
も用いられている。然しとの方法を篗用する際には， 用うるパラフインの良否，その時の氣溫等によつて著 しく條件がり，之の都度バラフインの混合等をしな ければならない。纎維のような比較的硬いるのを切 る塄合には，瀻維の硬さとパラフインの硬さとが異る ため，餘程切れる刀を用いないと成功しない。その上 織維とパラフインとをなじませるには相虽の手數を必 要とする。

筆者は䋐維の橫斷面の作製法について色々の方泆を 試みたがパラフイン法では伸々良好な結果が得られな
いことを知つた（よい゙ラフフィンを用いれば皇結果が 得られると言うよらなととる閙いているが，良いバラ フインは大抵ドイッ製のものであつて入手不能のもの が多い)。特にパラフイッ切片をデッキグラス上にはり つけることが中ぬむつかてくて，莭白グリセリッ等を 用いてもキシロールで洗うと織維はばらばらに分散し たりして中ふ思わしい結果が得られなかつた。

诌が坎にのべる硝酸瀻維素をメタノ一几とニーテル との混合液にと加した液で包理して非常に良結果を得 たのでこ」に報告する。この方法は手數が此較的か」 らぬとと，就練を要しないとと，薄い切片のできると そ，材料が安價なとと等で他の方法に對してすぐれて いると思われる。

\section{方法}

病理組織の標本を作るには脫水に非常に手數と日数 とを要するものでする。瀻維のように含水量の少いる

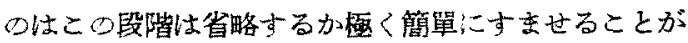
できる。筆者の經驗では一度の脫水で充分のようで亦 る。筆者俚包埋液の溶材と同じ組成のるの心夜間浸 清するようにしている。

次に本法の大荘を說明する。

硝酸織維素（セルロイドの原料として用いられるN 量 $10 \%$ 程度のもの，薄葉綎を確化したもの）をメタ ハールとェーテル混液にとかすのであるが，この際夯 の三在の液を作る。(これは一例を示したに過ざない， 原理は稀薄な夜より次第に清い液へサンプルを移して 行けばよいのである今の場合大體 $2.5 \%$, $5 \%$ ，10\% としたが，原料硝酸阵維素の重合度等によつて出來る 液の粘度が變るから必ずしも本處方通りにする必要は ない。最後の没の粘度は容器を傾けたとき，極く静加 に洨が流下する位のものがよい。粘度が低過ぎる包 埋物の收緶が箸しくなり，あまり粘度が高過ざると最 
後の包埋の操作からりにくい)。

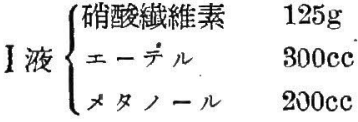

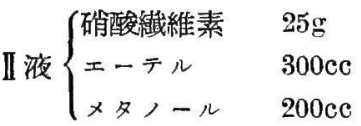
目液 $\begin{cases}\text { 确酸瀻維素 } & 50 \mathrm{~g} \\ \text { ×ーテル } & 300 \mathrm{cc} \\ \text { メタンール } & 200 \mathrm{cc}\end{cases}$

以下これを簡單に I， II，液と呼ぶことにする。

目液は最後に包埋に用らる液でするから用らるサンプ ルの數, 大いさ等に㷳じて少し多量に作る必要がある。 纎維を先ず $3: 2$ (上の各液の比率と同じ)の體積比の エーテル,メタノール湜液へ浸漬, この際氣泡等を完全 に追し出して，一夜間放置する。メタ, 一ルは市販の 99\%のものがよい。これで脫水を行うわけである。と れをピンセットで取出して手早くI液に入れる。民れ を一夜間放置（一夜間も入れて置かなくてもよいが， この方が獀驗操作がかえつて便利であるから筆者は一 夜間漫漬することにしている。5 時間位で充分と思わ れるこの䦎氣泡ができたら硝子棒で追い出す。この ようにして II, 四液えと進む。サンプルの形は第 1 圆

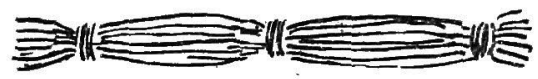

\section{英 1 回}

のように瀻維を束にして糸で結んでおくとよい。鼠後 に四液に一夜間浸漬したるのは瀻維と液とが完全にな じんでいるらこのま、静かに乾燥させれば包埋は終

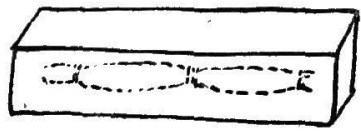

第 2 田
るのである。包埋に は，第さ圖に示すよ らに細長い、紙の函を 作り(この紙はハガ キの紙がよい，函の

橫に織維の名前なり番號なりを墨で畫いてて置くとよ い,これに四液を静かに氣泡の入らないように2/3 位 末でれ，乙の上に瀻維束（四液の容器內にあつたも の）を静加入れ，更にその上に山盛りになるまで川 液を充し，とれを度口の標本ビンの中へ入れ，ふたを して置く。急激に溶媒を蒸發させると表面に白い膜が 出來て，不均一に凝固寸るから上にのべたように槽本 ビンの中で,時ふふたをとつてやつて，静かに溶媒を蒸
發させてやる。二日もすれで紙函の內容物は初めの 1/3 位になる。この上に更に回液を山盛りになるまで 加えてやると，雨泡は出來易い（との時は氣泡は出來 ても差支えない）が切片を作るときに刀を使い易い。 しかてこれはやらなくてるよい。

時及函をとり出して刀で切机味をだめしてみて適當 な固さ（軟骨狀になつたとき）になつたとさとり出し て切片を作示ばよい(函に用いた紙はナイフで剈り取 つて括く方がよい)。適當な粘りをるつて居り，といつ て刀にへばりつく程の粘りはなく，その切れ味は極め， て良好である。切り終つたるのは 70一80\%のメタノ ール水溶液中に沈めて置けば，とれ以上固くなるとと はなく保存することができる。ミクロトームを用らる 場合には上の包埋物を適當な形に切つで, 四液を用い て臺木に固着させればよい。手切りの場合'（筆者は大 低とれを用いている。以下むげる舁值も手切りで得た もので克る)はそのま〉切る。

切片はそのま」デッキグラスの上にのせ，その上に 80\%位のメタノールを一滴落しててしわをのばして後水 浸して檢鏡する。筆者は別にこれをデッキグラスの上 にはりつける操作をしなかつたが，染色を行うときに はこれが必要であろう。

以上少し群しく本法の手續きを說明したが，本法の 利點とするところをあげれば,

(1) 操作が簡單ひ，失敗が少く，よい切片が得られる こと。

(2) 材料が安昜に手に入り易いるのであるとと。 缺點としては

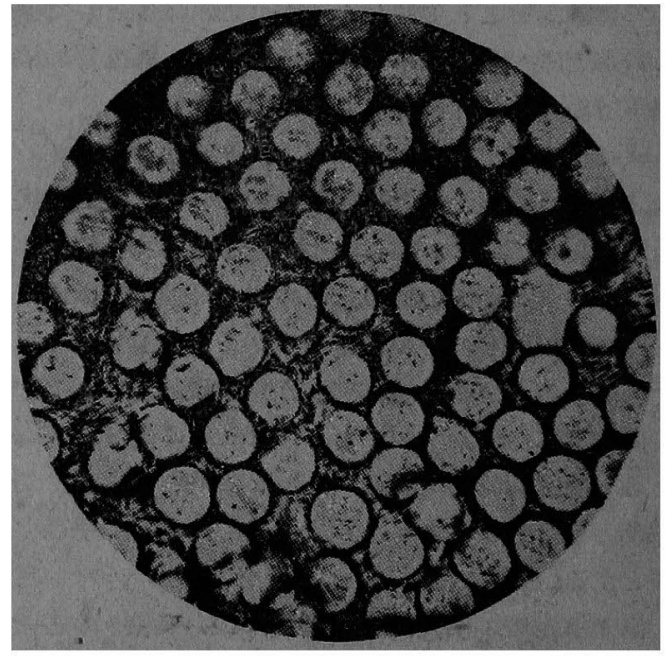

第3澏 ナイロ 


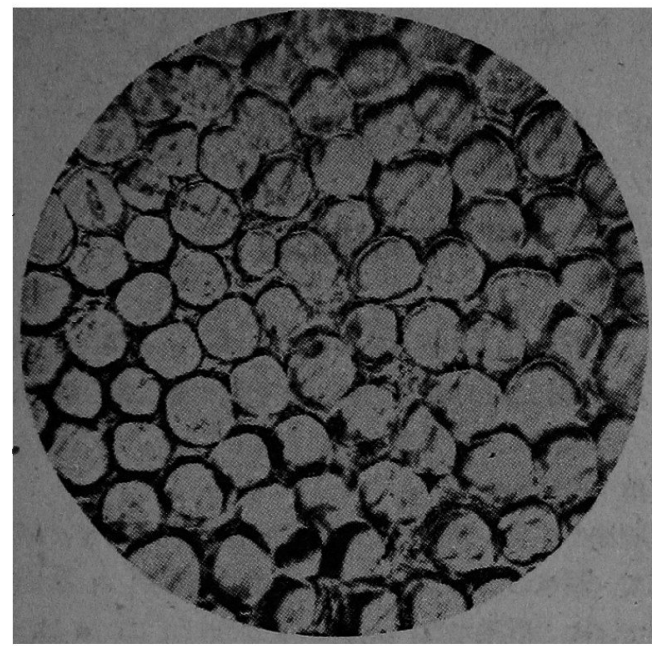

第 4 圖 ア ミ ラン $(x 500)$

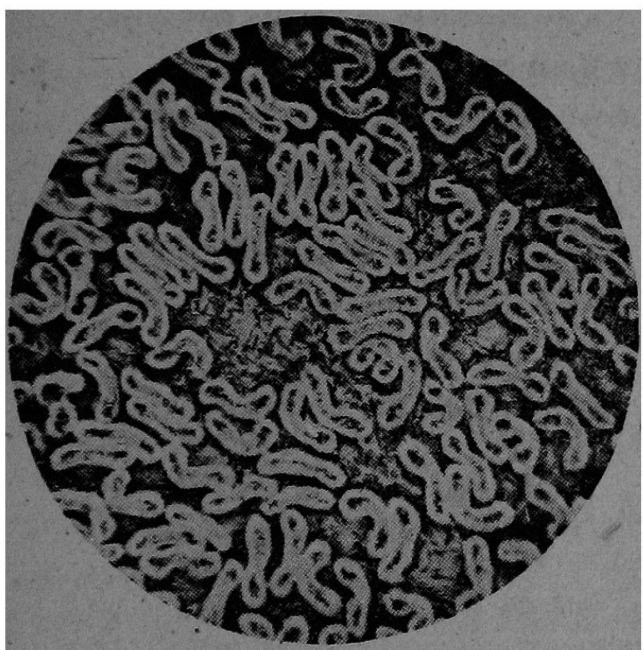

第5圖 ピ = ロ ン $(\times 500)$

（1）溶媒を用うるため，これにとける緎維には䧺用 できないと（例えば醋酸レーョンには瞧用できない。

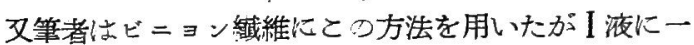
夜浸漬したぶけで瀻維が著しく收縮して斷面をとるこ とができなからた。

\section{ニ，三の合成㵶維に對する應用}

第 3，4，5，6 圖に夫及，ナイロン，アミランビ ニロン，ビスコーススフの斷面舁稹を示した。感光材 料の關係上むまり鮮明ではないが繊維の大體の輪廓を 知ることができる。倍率は全部同じで 500 倍である。

ナイロンは警くべき程均一な断面をもつている。人 カでこのような細く均一なものが多量に生産されるこ

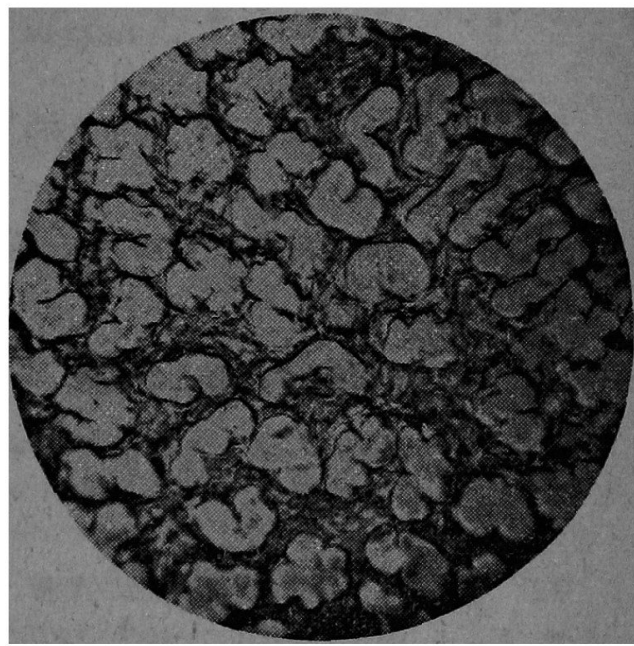

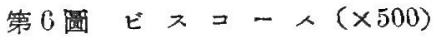

とは正に一驚威で㐫る。又ナイロンは維鵌の中に氣泡 狀のものを認めるがアミランにはこれがない。同じポ リアミド繊維でするが，その紡系條件が異るためです

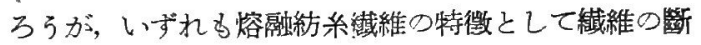
面は圓形である。

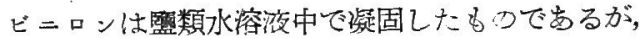
その斷面は醋酸人絹つそれににている。唯前者の場合 表皮とその內部がはつきり區別される。配列は表面の み起つて內部では起らないために生した纎維っ不均一 汇よるものか。人絹つように配列の範偉をるつと廣く すればるつと强い藏維ができるのでは岕るまいか。い ずれにしても最近ビニロンに關する研究出相當活潑に 行われているようで岁るからこれらの點は間もなく解 決されることであろう。

追記，本研究にあたつて䈎野美子氏つ御熱心な協力 を得た。感謝する゙次第である。 